\title{
Sex Positivity and the Persistence of Shame
}

\author{
John Mercer, Birmingham Centre for Media and Cultural Research \\ Sage, Sexualities. Volume: 21 issue: 8, page(s): 1304-1307
}

DOI: $10.1177 / 1363460718770443$

In the run up to this anniversary year for the journal I have found myself discussing the trajectory of my own research over the past 20 years on more than one occasion; an activity that always gives pause for thought and reflection. At the recent conference Doing Sex: Men, Masculinity and Sexual Practices Conference, hosted at Newcastle University in July 2017 where my presentation was a reflection on sexualized masculinity in porn and popular culture more widely I was inevitably interested to withness the ways in which debates around masculinity, sex and sexuality interact and are articulated across a range of domains and field of study including sociology, sports and health studies, media and cultural studies and anthropology. Whilst the conference showcased a wealth of research with a disparate range of objects of study, theoretical frameworks and methodological approaches, running across many of the presentations there was a unifying (or at least an underlying) theme that I had not expected. I found myself taken by the extent to which shame is routinely used as a term to frame the experience of sexuality. Porn consumption is associated with shame, gay men's use of hook-up apps is enmeshed with feelings of shame in complex and contradictory ways, all manner of sexual activities carry a burden of shame for their participants and of course sex work is still often seen as shameful. Shame then is a powerful (and negative) emotion often associated with sex and sexuality, shaming is a mechanism for social and personal control. Shame is internalized, pervasive and pacifying, we both feel shame and are subjected to shame. It is striking to note that, to borrow Jack Halberstam's description, shame is still an "active rubric of identification" (2005:219) and that shame is enmeshed into the ways in which so many people continue to experience and express their experience of sex and sexuality.

How then can we make sense of the persistence of shame in the $20^{\text {th }}$ anniversary year of Sexualities and a broader contemporary context in which the discourse of sex 
positivity has become predominant? I think this is an important moment in the development of the field to consider the status of sexual shame, not least because the discourse of sex positivity produces a call to action predicated on a repudiation of shame; shame as regressive, ignorant, reactionary and politically suspect.

Inevitably I have a personal investment in thinking through what sexual shame means now and as a gay man and a scholar who has written about articulations of masculinity in gay culture (and gay porn in particular) I have my own particular relationship to shame. For a major part of my early adult life being gay was associated with shame and likewise gay porn as a commodity and as a form of representation and as a mode of cultural consumption has likewise often been viewed in terms of shame. Consequently, for gay men shame (and the rejection of shame) for men of my generation was/is regarded as an inherently political act. As David Halperin observes in How To Be Gay;

There were, however, some queer emotions that gay people were not supposed to have, and that were not politically respectable. [...] bad gay emotions included narcissism, shame, self-loathing, passivity, sentimentality, cowardice, [...] Unlike grief and anger, these emotions were merely personal, in the sense that they expressed not group identity but individual failings. (2012: 79)

Given the slew of media coverage, TV and radio programming and arts and cultural events in 2017 staged to commemorate 50 years since the (partial) decriminalization of homosexuality in the UK, one could be forgiven for thinking that gay shame at least (and it's important to note that gay shame isn't the only kind of sexual shame that should matter for the field) was condemned to the past and that the work of gay rights activists had been done. Nonetheless shame has a peculiar, even uncanny power over those it inhabits and the discourses of pro-sex Feminism, sex positivity or indeed gay pride have not dislodged its pervasive influence on the ways we make meaning out of sex. The persistence of shame then presents a challenge for the field. Is the job of sexualities research to challenge and critique shame? Is there perhaps use in the strategic mobilization of shame as a critical category or political tool? 
I am not of course suggesting here that the particularities, contexts and conditions of sexual shame are a complete blind spot for the field. Indeed shame has been an especially fruitful line of enquiry in the development of queer theory including but not limited to the early work of Eve Kosofsky Sedgwick (1993), and more recently Jack Halberstam (2005) Lauren Berlant (2009) Sally Munt's Queer Attachments (2009) and the interventions of Sara Ahmed (2004). Queer theory then provides a substantial body of literature and a highly developed critical perspective through which to situate shame's mechanisms and operations as an object of enquiry for the study of sexualities in the $21^{\text {st }}$ century and perhaps a method for the strategic rethinking of what shame is (and does). Eve Kosofsky Sedgwick for instance in her much cited interrogation of gay shame argues that shame is 'identity constituting' (1993:5). In the introduction to their edited collection Gay Shame, David Halperin and Valerie Traub party in response to Sedgwick's position talk about the ways in which the blinkered optimism of gay pride was to become an, 'increasingly exhausted and restrictive ethos' (2009:5). ${ }^{1}$ This line of argument suggests that there is a strategic value in embracing rather than repudiating shame. As Sara Ahmed notes in 'Queer Feelings' in The Cultural Politics of Emotion suggests:

Such affirmation would not be about the conversion of shame into pride, but the enjoyment of the negativity of shame, an enjoyment of that which has been designated shameful by normative culture. (2004: 146)

Consequently I think that rather than thinking about sexual shame as an anachronism of a pre-sex positive social and cultural landscape there is a continued necessity to interrogate shame and a way into that critical engagement that is both informed by queer theory but extends beyond the specifics of that domain of knowledge. As João Florencio's call to action suggests in his recent presentation on shame and HIV:

Rather than trying too quickly to find strategies to overcome shame, perhaps we could dwell in its uncanny, queer temporality for a little longer, and use it as an affective suspension of normative time. (2017) ${ }^{2}$

A route into how we might make continue to think critically about sexual shame and furthermore, why sexual shame continues to hold purchase and have significance in 
the $21^{\text {st }}$ century is offered, unsurprisingly, by Jack Halberstam. In a forensic critique written in response to the "Gay Shame" conference at University of Michigan, Halberstam sees fundamental problems with a romanticisation of gay shame and the predominance of white gay male voices. In 'White Masculinity and Gay Shame' Halberstam goes on to argue that:

We cannot completely do without shame and that shame can be a powerful tactic in the struggle to make privilege (whiteness, masculinity, wealth) visible. (2005:220)

I think it is in this observation that what Jack Halberstam suggests acts as a useful corrective and points to at least one productive direction for the field. Explorations of shame draw our attention to the manifestations and operations of privilege. The locations of shame make privilege visible to us and function as reminders to researchers of sex and sexuality why, just as sexual shame is a persistent phenomena, so the necessity to critically interrogate sex and sexuality is as urgent as it ever was.

\section{References}

Ahmed, S. (2004) The Cultural Politics of Emotion. Edinburgh, Edinburgh University Press.

Berlant, L. Najafi, S. and Serlin, D (2008) 'The Broken Circuit: an Interview with Lauren Berlant', Cabinet Magazine, Issue 31, Shame Fall http://www.cabinetmagazine.org/issues/31/najafi_serlin.php

Florencio, J. (2017) 'Shame and HIV: A Visual Culture Approach' paper presented to the Shame and Medicine Workshop, Trinity College Dublin, 19 September 2017 Halberstam , J. (2005) 'Shame and White Gay Masculinity', Social Text 84/85 Vol. 23. No. 3-4

Halperin, D. (2012) How to be Gay. New York, Harvard University Press.

Halperin, D and Traub, V. (2009) 'Beyond Gay Pride' in Halperin \& Traub (eds) Gay Shame, Chicago: University of Chicago Press.

Kosofsky Sedgwick, E. (1993) 'Queer Performativity: Henry James's The Art of the Novel' GLQ: A Journal of Lesbian and Gay Studies November 1993 1(1): 1-16 Muñoz, J. (2009) Cruising Utopia: The Then and There of Queer Futurity. New York: NYU Press.

Munt, S. (2009) Queer Attachments: The Cultural Politics of Shame. London: Routledge. 


\section{NOTES}

${ }^{1}$ See also Muñoz' Cruising Utopia: The Then and There of Queer Futurity (2009) ${ }^{2}$ I'm indebted to João Florencio for sharing the manuscript of his conference presentation with me in the preparation of this essay. 